\title{
Influence of an international consensus conference on practice patterns in advanced prostate cancer
}

\author{
Authors: J. Gong ${ }^{1,2}$, A. Omlin ${ }^{3}$, S.K. Pal ${ }^{1}$, J. Hsu ${ }^{1}$, B. Tombal ${ }^{4}$, M.R. Sydes ${ }^{5}$, S. Gillessen ${ }^{3}$ \\ ${ }^{1}$ Department of Medical Oncology, City of Hope National Medical Center, Duarte, CA, USA \\ ${ }^{3}$ Department of Oncology/Haematology, Kantonsspital St Gallen, St Gallen, Switzerland \\ University Hospital Berne, Department of Oncology and Haematology, Berne, Switzerland \\ ${ }^{4}$ Service d'Urologie, Institut de Recherche Clinique, Université Catholique de Louvain, Brussels, \\ Belgium \\ ${ }^{5} \mathrm{MRC}$ Clinical Trials Unit at UCL, Institute of Clinical Trials and Methodology, University \\ College London, London, UK \\ ${ }^{2}$ Corresponding Author: Dr. Jun Gong, Department of Medical Oncology, City of Hope National \\ Medical Center, 1500 E Duarte Rd, Bldg 51, Duarte, CA, 91010, USA, Tel: 626-471-9200, Fax: \\ 626-301-8233, Email: jgong@ coh.org
}

Keywords

Advanced Prostate Cancer Consensus Conference, consensus survey, expert panel, prostate cancer

Text: 506 words 


\section{Letter to the Editor}

\section{Research Letter}

The St. Gallen Advanced Prostate Cancer Consensus Conference (APCCC) convened in 2017 to provide expert consensus on areas of advanced prostate cancer (APC) management where there is limited or conflicting evidence [1]. We administered 57 questions as a pre- and post-conference survey to all attendees who were not part of the panel. These multiple choice questions were selected from the 150 questions for expert panelists at APCCC 2017. Consensus was declared if $\geq 75 \%$ participants who did not "abstain" or declare themselves "unqualified" selected the same answer [1].

From 02/2017-04/2017, matched responses from 120 non-panel-member attendees before and after APCCC 2017 were compared to identify changes in attendee treatment preferences in APC (Supplemental Table 1). Attendees reached a consensus on pre- and post-conference surveys on 9/57 questions (Supplemental Table 2). A change from a $<75 \%$ consensus vote to $\geq 75 \%$ vote (or vice-versa) was seen in 3 key topics (Supplemental Figures 1-2): first-line treatment option for patients with metastatic castrate-resistant prostate cancer (mCRPC) progressing on the docetaxel they had in the castrate-naïve setting; duration of osteoclasttargeted therapy in mCRPC; and imaging modality for both mCRPC and metastatic castratenaïve prostate cancer (mCNPC). Although participants did not reach a consensus on 48/57 (84\%) questions in both pre- and post-conference questionnaires, there were 6 topics in which a $\geq 15 \%$ increase in the most popular category from pre- to post-conference surveys was observed (Table 1). Specifically, there were notable increases in certain answer options after than before the conference in topics on: genetic counseling; adding androgen-deprivation therapy (ADT) to salvage radiation; defining oligometastases; osteoclast-targeted therapy with ADT; and 
multidisciplinary care. Participants disagreed with the panelists in majority votes on 11/57 questions (Supplemental Table 3).

This study is among the first to describe changes in healthcare provider preferences in APC management based on comparison of pre- and post-conference surveys following attendance of an international consensus conference providing state-of-the art lectures, interactive debates, and expert panelist voting. Recent investigations have highlighted that provider practices can be influenced by consensus conferences, including those that engage participants with interactive and mixed educational sessions incorporating web-based and/or mobile technology [2-5].

One important message conveyed by the APCCC 2017 expert panel and non-panel member surveys is the lack of consensus on many topics in APC management (Supplemental Table 4). Our work brings greater attention to topics where further study is warranted in APC management. Notably, we observed clear shifts in attendee responses where a loss of attendee consensus from pre- to post-conference or gain of attendee post-conference consensus when preconference consensus was not reached and increases in majority votes from pre- to postconference occurred. Importantly, the majority of these changes between pre- and- postconference participant responses followed voting for the same answer options by the majority of panelists, which provides proof that consensus conferences such as APCCC 2017 offer a unique learning experience. The next APCCC conference in 2019 is planned (apccc.org) and, again, a selection of key questions will be circulated pre- and post-conference to participants; we hope for an even better return rate of the surveys. 


\section{References}

1. Gillessen S, Attard G, Beer TM, et al. Management of patients with advanced prostate cancer: The report of the Advanced Prostate Cancer Consensus Conference APCCC 2017. Eur Urol. 2017:doi:10.1016/j.eururo.2017.1006.1002.

2. Leung CP, Klausner AP, Habibi JR, King AB, Feldman A. Audience response system: a new learning tool for urologic conferences. Can J Urol. 2013;20:7042-7045.

3. Nelson DM, Peterson AC. Changes in bone health and skeletal-related events following implementation of a multidisciplinary consensus statement guiding surveillance and treatment of men undergoing androgen deprivation therapy for prostate cancer. Aging Male. 2010;13:120123.

4. Billis A, Guimaraes MS, Freitas LL, Meirelles L, Magna LA, Ferreira U. The impact of the 2005 international society of urological pathology consensus conference on standard Gleason grading of prostatic carcinoma in needle biopsies. J Urol. 2008;180:548-552.

5. Davis D, O'Brien MA, Freemantle N, Wolf FM, Mazmanian P, Taylor-Vaisey A. Impact of formal continuing medical education: do conferences, workshops, rounds, and other traditional continuing education activities change physician behavior or health care outcomes?

JAMA. 1999;282:867-874. 
Supplemental Figure 1. Topics Reaching Consensus $\geq 75 \%$ Votes on Post- but NOT Pre-Conference Surveys. mCRPC, metastatic castrate-resistant prostate cancer

Supplemental Figure 2. Topics Reaching Consensus $\geq 75 \%$ Votes on Pre- but NOT Post-Conference Surveys. mCNPC, metastatic castrate-naïve prostate cancer; mCRPC, metastatic castrate-resistant prostate cancer; CT, computed tomography; wbMRI, whole-body magnetic resonance imaging; PET/CT, positron emission tomography-computed tomography 
Table 1. Topics Not Reaching Consensus $\geq 75 \%$ Votes on either Pre- and PostConference Surveys but with $\geq \mathbf{1 5 \%}$ Change in Votes from Pre- to Post-Conference Surveys ${ }^{\mathrm{a}}$

\begin{tabular}{|c|c|c|c|c|}
\hline \multirow[t]{2}{*}{ Question } & \multirow[t]{2}{*}{ Answer } & \multirow[t]{2}{*}{ Panelists } & $\begin{array}{c}\text { Pre- } \\
\text { conference }\end{array}$ & $\begin{array}{l}\text { Post- } \\
\text { conference }\end{array}$ \\
\hline & & & No. $(\%)$ & No. $(\%)$ \\
\hline $\begin{array}{l}\text { Do you recommend genetic } \\
\text { counseling and testing for men } \\
\text { with newly diagnosed } \\
\text { metastatic (M1) prostate } \\
\text { cancer? }\end{array}$ & $\begin{array}{l}\text { Yes, in a minority of } \\
\text { selected patients }\end{array}$ & $62 \%$ & $\begin{array}{l}58 / 118 \\
(49.15 \%)\end{array}$ & $\begin{array}{l}76 / 116 \\
(65.52 \%)\end{array}$ \\
\hline $\begin{array}{l}\text { At what confirmed PSA level } \\
\text { do you recommend starting } \\
\text { salvage radiation therapy in the } \\
\text { majority of men with isolated } \\
\text { rising PSA alone after } \\
\text { prostatectomy? }\end{array}$ & $0.2 \mathrm{ng} / \mathrm{mL}$ & $44 \%$ & $\begin{array}{l}61 / 117 \\
(52.14 \%)\end{array}$ & $\begin{array}{l}82 / 116 \\
(70.69 \%)\end{array}$ \\
\hline $\begin{array}{l}\text { Do you recommend adding } \\
\text { ADT in combination with } \\
\text { salvage radiation therapy? }\end{array}$ & $\begin{array}{l}\text { Yes, in the majority } \\
\text { of patients }\end{array}$ & $61 \%$ & $\begin{array}{l}34 / 117 \\
(29.06 \%)\end{array}$ & $\begin{array}{l}57 / 116 \\
(49.14 \%)\end{array}$ \\
\hline $\begin{array}{l}\text { What is your cut-off for the } \\
\text { number of metastases to } \\
\text { consider a patient as } \\
\text { oligometastatic? }\end{array}$ & $\leq 3$ metastases & $66 \%$ & $\begin{array}{l}56 / 115 \\
(48.70 \%)\end{array}$ & $\begin{array}{l}80 / 113 \\
(70.80 \%)\end{array}$ \\
\hline $\begin{array}{l}\text { Do you recommend drug } \\
\text { therapy to prevent bone loss } \\
\text { and/or fractures with } \\
\text { denosumab or a bisphosphonate } \\
\text { for osteoporosis prophylaxis in } \\
\text { men with PC starting on ADT? }\end{array}$ & $\begin{array}{l}\text { Only in patients with } \\
\text { documented } \\
\text { osteopenia or } \\
\text { osteoporosis }\end{array}$ & $70 \%$ & $\begin{array}{l}49 / 115 \\
(42.61 \%)\end{array}$ & $\begin{array}{l}67 / 113 \\
(59.29 \%)\end{array}$ \\
\hline $\begin{array}{l}\text { Do you recommend to routinely } \\
\text { involve a multidisciplinary team } \\
\text { for prevention or management }\end{array}$ & $\begin{array}{l}\text { Yes, in the majority } \\
\text { of selected patients } \\
\text { (Panelists) }\end{array}$ & $42 \%$ & $\begin{array}{l}29 / 115 \\
(25.22 \%)\end{array}$ & $\begin{array}{l}51 / 113 \\
(45.13 \%)\end{array}$ \\
\hline of ADT-related adverse effects? & $\begin{array}{l}\text { Yes, in a minority of } \\
\text { selected patients } \\
\text { (Participants) }\end{array}$ & & & \\
\hline
\end{tabular}

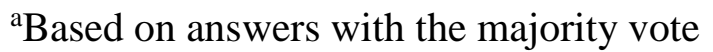
PSA, prostate-specific antigen; ADT, androgen deprivation therapy; PC, prostate cancer 


\section{Supplementary Table 1. Participant Background and Characteristics}

\begin{tabular}{|lll|}
\hline Participant Characteristic (n=120) & \multicolumn{2}{l|}{ Number(\%) } \\
\hline Geographic Region & & \\
Europe & 91 & $(75.8 \%)$ \\
Asia-Pacific & 13 & $(10.8 \%)$ \\
South America & 10 & $(8.3 \%)$ \\
Africa/Middle East & 4 & $(3.3 \%)$ \\
North America & 2 & $(1.7 \%)$ \\
Gender & & \\
Male & 89 & $(74.2 \%)$ \\
Female & 31 & $(25.8 \%)$ \\
Profession & & \\
Medical Oncologist & 50 & $(41.7 \%)$ \\
Urologist & 49 & $(40.8 \%)$ \\
Clinical Oncologist & 11 & $(9.2 \%)$ \\
Radiation Oncologist & 8 & $(6.7 \%)$ \\
Radiologist & 1 & $(0.8 \%)$ \\
Other & 1 & $(0.8 \%)$ \\
Professional Experience & & \\
Consultant $>10$ years & 75 & $(62.5 \%)$ \\
Consultant 5-10 years & 24 & $(20.0 \%)$ \\
Consultant <5 years & 16 & $(13.3 \%)$ \\
Trainee & 4 & $(3.3 \%)$ \\
Other & 1 & $(0.8 \%)$ \\
Setting of Practice & & \\
Tertiary care/specialist hospital/referral & 65 & $(54.2 \%)$ \\
hospital in high income country & & \\
Tertiary care/specialist hospital/referral & 21 & $(17.5 \%)$ \\
hospital in low-to-middle income & & \\
country & & \\
Local hospital in high income country & 20 & $(16.7 \%)$ \\
Private practice in high income country & 7 & $(5.8 \%)$ \\
Private practice in high income country & 6 & $(5.0 \%)$ \\
in low-to-middle income country & & \\
Local hospital in low-to-middle income & 1 & $(0.8 \%)$ \\
country & & \\
Research & 61 & $(50.8 \%)$ \\
Clinic work + protected academic time \\
All clinical work & 58 & $(48.3 \%)$ \\
All academic time & 1 & $(0.8 \%)$ \\
Open Prostate Cancer Trials for Accrual & & \\
1-4 & 46 & $(38.3 \%)$ \\
5-10 & 32 & $(26.7 \%)$ \\
0 & 30 & $(25.0 \%)$ \\
>10 & 12 & $(10.0 \%)$ \\
\hline
\end{tabular}




\begin{tabular}{|lll|}
\hline Participant Characteristic (n=120) & \multicolumn{2}{l|}{ Number(\%) } \\
\hline Drugs Registered in Clinic & 115 & $(96.6 \%)$ \\
Docetaxel (CRPC) & 114 & $(95.8 \%)$ \\
Abiraterone (post-chemotherapy) & 112 & $(94.1 \%)$ \\
Cabazitaxel & 111 & $(93.3 \%)$ \\
Enzalutamide (post-chemotherapy) & 110 & $(92.4 \%)$ \\
Abiraterone (pre-chemotherapy) & 110 & $(92.4 \%)$ \\
Enzalutamide (pre-chemotherapy) & 99 & $(83.2 \%)$ \\
Docetaxel (CNPC) & 95 & $(79.8 \%)$ \\
Radium-223 & 3 & $(2.5 \%)$ \\
Sipuleucel-T & 112 & $(95.7 \%)$ \\
Drugs Registered and Reimbursed in Clinic & 107 & $(91.5 \%)$ \\
Docetaxel (CRPC) & 105 & $(89.7 \%)$ \\
Abiraterone (post-chemotherapy) & 103 & $(88.0 \%)$ \\
Enzalutamide (post-chemotherapy) & 97 & $(82.9 \%)$ \\
Cabazitaxel & 95 & $(81.2 \%)$ \\
Abiraterone (pre-chemotherapy) & 88 & $(75.2 \%)$ \\
Enzalutamide (pre-chemotherapy) & 85 & $(72.7 \%)$ \\
Docetaxel (CNPC) & 3 & $(2.5 \%)$ \\
Radium-223 & & \\
Sipuleucel-T & 118 & $(99.2 \%)$ \\
Imaging Modalities Available in Clinic & 114 & $(95.8 \%)$ \\
Computed tomography & & \\
Conventional MRI (spine, pelvis, other \\
region) & 113 & $(95.0 \%)$ \\
Bone scintigraphy & 65 & $(54.6 \%)$ \\
Whole-body MRI & 62 & $(52.1 \%)$ \\
Choline-PET-CT & 47 & $(39.5 \%)$ \\
PSMA-PET-CT & 37 & $(31.1 \%)$ \\
Fluoride-PET-CT & 3 & $(2.5 \%)$ \\
Fluciclovine-PET-CT & & \\
& & \\
\end{tabular}

${ }^{a}$ May not total to $100 \%$ due to rounding and may not total to 120 due to multiple responses allowed, when applicable

CRPC, castrate-resistant prostate cancer; CNPC, castrate-naïve prostate cancer; MRI, magnetic resonance imaging; PET-CT, positron emission tomography-computed tomography; PSMA, prostate-specific membrane antigen 


\section{Supplementary Table 2. Topics Reaching Consensus $\geq 75 \%$ Votes with Panelists and both Pre- and Post-Conference Surveys ${ }^{\mathrm{a}}$}

\begin{tabular}{|c|c|c|c|c|}
\hline \multirow[t]{2}{*}{ Question } & \multirow[t]{2}{*}{ Answer } & Panelists & Pre-Conference & Post-Conference \\
\hline & & $(\%)$ & No. $(\%)$ & No. $(\%)$ \\
\hline $\begin{array}{l}\text { Do you recommend docetaxel and ADT } \\
\text { in de novo mCNPC with high volume } \\
\text { disease? }\end{array}$ & $\begin{array}{l}\text { Yes, in the } \\
\text { majority of } \\
\text { patients }\end{array}$ & $96 \%$ & $95 / 120(79.17 \%)$ & $104 / 117(88.89 \%)$ \\
\hline $\begin{array}{l}\text { If you use chemo-hormonal therapy in } \\
\text { mCNPC, which chemotherapy regimen } \\
\text { do you recommend for the majority of } \\
\text { patients? }\end{array}$ & $\begin{array}{l}\text { 3-weekly } \\
\text { regimen of } \\
\text { docetaxel with } \\
75 \mathrm{mg} / \mathrm{m}^{2}\end{array}$ & $96 \%$ & $91 / 120(75.83 \%)$ & $102 / 117(87.18 \%)$ \\
\hline $\begin{array}{l}\text { Do you recommend docetaxel and ADT } \\
\text { in non-metastatic CNPC (NOM0) with } \\
\text { biochemical relapse? }\end{array}$ & No & $90 \%$ & $103 / 120(85.83 \%)$ & $107 / 117(91.45 \%)$ \\
\hline $\begin{array}{l}\text { What is your preferred first-line mCRPC } \\
\text { treatment in the majority of } \\
\text { asymptomatic or minimally symptomatic } \\
\text { men who did NOT receive docetaxel in } \\
\text { the castrate-naïve setting? }\end{array}$ & $\begin{array}{l}\text { Abiraterone or } \\
\text { enzalutamide }\end{array}$ & $86 \%$ & $98 / 120(81.67 \%)$ & $106 / 116(91.38 \%)$ \\
\hline $\begin{array}{l}\text { What is your preferred first-line mCRPC } \\
\text { treatment in the majority of } \\
\text { asymptomatic or minimally symptomatic } \\
\text { men who did receive docetaxel in the } \\
\text { castrate-naïve setting? }\end{array}$ & $\begin{array}{l}\text { Abiraterone or } \\
\text { enzalutamide }\end{array}$ & $90 \%$ & $105 / 120(87.50 \%)$ & $110 / 116(94.83 \%)$ \\
\hline $\begin{array}{l}\text { What is your preferred second-line } \\
\text { mCRPC treatment in the majority of } \\
\text { symptomatic men who had PD as best } \\
\text { response to first-line abiraterone or } \\
\text { enzalutamide? }\end{array}$ & Taxane & $96 \%$ & $104 / 120(86.67 \%)$ & $102 / 116(87.93 \%)$ \\
\hline $\begin{array}{l}\text { What is your preferred second-line } \\
\text { mCRPC treatment in the majority of } \\
\text { symptomatic men with acquired } \\
\text { resistance (initial response followed by } \\
\text { PD) after first-line abiraterone or } \\
\text { enzalutamide? }\end{array}$ & Taxane & $90 \%$ & $95 / 120(79.17 \%)$ & $97 / 116(83.62 \%)$ \\
\hline $\begin{array}{l}\text { What is your preferred second-line } \\
\text { mCRPC treatment in the majority of } \\
\text { asymptomatic/minimally symptomatic } \\
\text { men progressing on or after docetaxel } \\
\text { (without prior abiraterone or } \\
\text { enzalutamide)? }\end{array}$ & $\begin{array}{l}\text { Abiraterone or } \\
\text { enzalutamide }\end{array}$ & $92 \%$ & $103 / 120(85.83 \%)$ & $102 / 116(87.93 \%)$ \\
\hline $\begin{array}{l}\text { Do you recommend regular physical } \\
\text { exercise in men with PC starting on } \\
\text { ADT? }\end{array}$ & $\begin{array}{l}\text { Yes, in the } \\
\text { majority of } \\
\text { patients }\end{array}$ & $98 \%$ & 105/115 (91.30\%) & $108 / 113(95.58 \%)$ \\
\hline
\end{tabular}

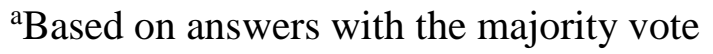


${ }^{\mathrm{b}}$ As defined by CHAARTED (visceral [lung or liver] and/or 4 bone metastases, at least one beyond pelvis and vertebral column; Sweeney CJ, Chen YH, Carducci M, et al. Chemohormonal therapy in metastatic hormone-sensitive prostate cancer. N Engl J Med. 2015;373:737-746)

ADT, androgen deprivation therapy; mCNPC, metastatic castrate-naïve prostate cancer; mCRPC, metastatic castrate-resistant prostate cancer; PD, progressive disease; PC, prostate cancer 


\section{Supplementary Table 3. Discordant Answers between Panelists and Participants}

\begin{tabular}{|c|c|c|c|c|c|}
\hline \multirow[t]{2}{*}{ Question } & \multicolumn{2}{|c|}{ Panelists } & \multirow{2}{*}{$\begin{array}{c}\text { Participants } \\
\text { Answer }\end{array}$} & \multirow{2}{*}{$\begin{array}{c}\begin{array}{c}\text { Pre- } \\
\text { Conference }\end{array} \\
\text { No. }(\%)\end{array}$} & \multirow{2}{*}{$\begin{array}{c}\begin{array}{c}\text { Post- } \\
\text { Conference }\end{array} \\
\text { No. }(\%)\end{array}$} \\
\hline & Answer & $(\%)$ & & & \\
\hline $\begin{array}{l}\text { What is your preferred first-line } \\
\text { mCRPC treatment in the } \\
\text { majority of symptomatic men } \\
\text { who did NOT receive docetaxel } \\
\text { in the castration-naïve setting? }\end{array}$ & $\begin{array}{l}\text { Abiraterone or } \\
\text { enzalutamide }\end{array}$ & $52 \%$ & Docetaxel & $\begin{array}{l}63 / 120 \\
(52.50 \%)\end{array}$ & $\begin{array}{l}58 / 116 \\
(50.00 \%)\end{array}$ \\
\hline $\begin{array}{l}\text { What is your preferred first-line } \\
\text { mCRPC treatment option in the } \\
\text { majority of symptomatic men } \\
\text { who received chemo-hormonal } \\
\text { therapy and who progressed } \\
\text { within } \leq 6 \text { months of docetaxel } \\
\text { in the castration-naïve setting? }\end{array}$ & $\begin{array}{l}\text { Abiraterone or } \\
\text { enzalutamide }\end{array}$ & $57 \%$ & Cabazitaxel & $\begin{array}{l}53 / 120 \\
(44.17 \%)\end{array}$ & $\begin{array}{l}54 / 116 \\
(46.55 \%)\end{array}$ \\
\hline $\begin{array}{l}\text { If you have to choose between } \\
\text { abiraterone and enzalutamide } \\
\text { what is your preferred first-line } \\
\text { choice for men with mCRPC } \\
\text { with no contraindication to } \\
\text { either drug? }\end{array}$ & $\begin{array}{l}\text { No preferred } \\
\text { choice }\end{array}$ & $37 \%$ & Abiraterone & $\begin{array}{l}39 / 120 \\
(32.50 \%)\end{array}$ & $\begin{array}{l}41 / 116 \\
(35.34 \%)\end{array}$ \\
\hline $\begin{array}{l}\text { In men with mCRPC who are } \\
\text { on treatment with abiraterone or } \\
\text { enzalutamide for bone and soft } \\
\text { tissue metastases and who are } \\
\text { progressing only in the bone, do } \\
\text { you recommend the addition of } \\
\text { radium-223? }\end{array}$ & $\begin{array}{l}\text { Yes, in the } \\
\text { majority of } \\
\text { patients }\end{array}$ & $43 \%$ & $\begin{array}{l}\text { Yes, in the } \\
\text { minority of } \\
\text { selected } \\
\text { patients }\end{array}$ & $\begin{array}{l}45 / 120 \\
(37.50 \%)\end{array}$ & $\begin{array}{l}51 / 116 \\
(43.97 \%)\end{array}$ \\
\hline $\begin{array}{l}\text { What imaging test is most } \\
\text { suitable to "exclude" distant } \\
\text { metastases in high-risk and } \\
\text { locally-advanced prostate } \\
\text { cancer? }\end{array}$ & $\begin{array}{l}\mathrm{CT} \text { and bone } \\
\text { scintigraphy }\end{array}$ & $41 \%$ & $\begin{array}{l}\text { PET/CT } \\
\text { (PSMA, } \\
\text { choline, or } \\
\text { fluciclovine) }\end{array}$ & $\begin{array}{l}69 / 118 \\
(58.47 \%)\end{array}$ & $\begin{array}{l}84 / 116 \\
(72.41 \%)\end{array}$ \\
\hline $\begin{array}{l}\text { If you recommend radical local } \\
\text { treatment plus ADT in men } \\
\text { with newly diagnosed } \\
\text { oligometastatic prostate cancer } \\
\text { and an untreated primary do } \\
\text { you recommend adding } \\
\text { docetaxel? }\end{array}$ & $\begin{array}{l}\text { Yes, in a } \\
\text { minority of } \\
\text { selected } \\
\text { patients }\end{array}$ & $39 \%$ & No & $\begin{array}{l}45 / 115 \\
(39.13 \%)\end{array}$ & $\begin{array}{l}40 / 113 \\
(35.40 \%)\end{array}$ \\
\hline $\begin{array}{l}\text { Do you recommend a baseline } \\
\text { measurement of vitamin D in } \\
\text { men with prostate cancer } \\
\text { starting on ADT? }\end{array}$ & $\begin{array}{l}\text { Yes, in the } \\
\text { majority of } \\
\text { patients }\end{array}$ & $43 \%$ & No & $\begin{array}{l}54 / 115 \\
(46.96 \%)\end{array}$ & $\begin{array}{l}46 / 113 \\
(40.71 \%)\end{array}$ \\
\hline $\begin{array}{l}\text { Do you recommend a baseline } \\
\text { measurement of bone mineral } \\
\text { density in men with prostate } \\
\text { cancer starting on ADT? }\end{array}$ & $\begin{array}{l}\text { Yes, in the } \\
\text { majority of } \\
\text { patients }\end{array}$ & $62 \%$ & No & $\begin{array}{l}55 / 115 \\
(47.83 \%)\end{array}$ & $\begin{array}{l}43 / 113 \\
(38.05 \%)\end{array}$ \\
\hline
\end{tabular}




\begin{tabular}{|c|c|c|c|c|c|}
\hline \multirow[t]{2}{*}{ Question } & \multicolumn{2}{|c|}{ Panelists } & \multirow{2}{*}{$\begin{array}{c}\text { Participants } \\
\text { Answer }\end{array}$} & \multirow{2}{*}{$\begin{array}{c}\begin{array}{c}\text { Pre- } \\
\text { Conference }\end{array} \\
\text { No. }(\%) \\
\end{array}$} & \multirow{2}{*}{$\begin{array}{c}\begin{array}{c}\text { Post- } \\
\text { Conference }\end{array} \\
\text { No. }(\%)\end{array}$} \\
\hline & Answer & $(\%)$ & & & \\
\hline $\begin{array}{l}\text { Do you recommend to routinely } \\
\text { involve a multidisciplinary } \\
\text { team for prevention or } \\
\text { management of ADT-related } \\
\text { adverse effects? }\end{array}$ & $\begin{array}{l}\text { Yes, in the } \\
\text { majority of } \\
\text { patients }\end{array}$ & $42 \%$ & $\begin{array}{l}\text { Yes, in a } \\
\text { minority of } \\
\text { selected } \\
\text { patients }\end{array}$ & $\begin{array}{l}29 / 115 \\
(25.22 \%)\end{array}$ & $\begin{array}{l}51 / 113 \\
(45.13 \%)\end{array}$ \\
\hline $\begin{array}{l}\text { Do you recommend a health } \\
\text { status assessment in men with } \\
\text { advanced prostate cancer } \geq 70 \\
\text { years before treatment } \\
\text { decision? }\end{array}$ & $\begin{array}{l}\text { Yes, in a } \\
\text { minority of } \\
\text { selected } \\
\text { patients }\end{array}$ & $42 \%$ & $\begin{array}{l}\text { Yes, in the } \\
\text { majority of } \\
\text { patients }\end{array}$ & $\begin{array}{l}46 / 115 \\
(40.00 \%)\end{array}$ & $\begin{array}{l}48 / 113 \\
(42.48 \%)\end{array}$ \\
\hline $\begin{array}{l}\text { If you recommend a health } \\
\text { status assessment in men with } \\
\text { advanced prostate cancer } \geq 70 \\
\text { years which one do you } \\
\text { recommend? }\end{array}$ & $\begin{array}{l}\text { Screening by } \\
\text { G8 only } \\
\text { (followed by } \\
\text { further } \\
\text { assessment if } \\
\text { score } \leq 14 \text { ) }\end{array}$ & $30 \%$ & $\begin{array}{l}\text { Comprehensive } \\
\text { Geriatric } \\
\text { Assessment }\end{array}$ & $\begin{array}{l}23 / 115 \\
(20.00 \%)\end{array}$ & $\begin{array}{l}24 / 113 \\
(21.24 \%)\end{array}$ \\
\hline
\end{tabular}

${ }^{\text {a}}$ Based on answers with the majority vote mCRPC, metastatic castrate-resistant prostate cancer; CT, computed tomography; PET-CT, positron emission tomography-computed tomography; PSMA, prostate-specific membrane antigen; ADT, androgen deprivation therapy 
Supplementary Table 4. Pre-selected 57 Questions and Pre- and Post-conference Survey Responses

\begin{tabular}{|c|c|c|c|c|}
\hline Question & Answer ${ }^{\mathrm{a}}$ & Panelists $^{\mathrm{b}}$ & Pre-conference & Post-conference \\
\hline $\begin{array}{l}\text { For the purpose of treatment } \\
\text { selection, what is the most } \\
\text { meaningful definition of high- } \\
\text { volume disease in castration-naïve } \\
\text { metastatic prostate cancer? }\end{array}$ & $\begin{array}{l}\text { As defined by } \\
\text { CHAARTED }^{\mathrm{c}} \text { (visceral } \\
\text { [lung or liver] and/or } 4 \\
\text { bone metastases, at } \\
\text { least one beyond pelvis } \\
\text { and vertebral column) }\end{array}$ & $74 \%$ & $\begin{array}{l}68 / 120 \\
(56.67 \%)\end{array}$ & $73 / 120(60.83 \%)$ \\
\hline $\begin{array}{l}\text { What kind of hormone therapy do } \\
\text { you recommend in the majority of } \\
\text { men presenting with high-volume } \\
\text { metastatic castration-naïve prostate } \\
\text { cancer? }\end{array}$ & $\begin{array}{l}\text { Continuous ADT using } \\
\text { a LHRH agonist (plus a } \\
\text { short course of first- } \\
\text { generation AR } \\
\text { antagonist to prevent } \\
\text { testosterone surge) }\end{array}$ & $68 \%$ & $\begin{array}{l}73 / 120 \\
(60.83 \%)\end{array}$ & $79 / 120(65.83 \%)$ \\
\hline $\begin{array}{l}\text { Do you recommend docetaxel in } \\
\text { addition to ADT in men with de } \\
\text { novo metastatic castration-naïve } \\
\text { prostate cancer and high volume } \\
\text { disease as defined by CHAARTED } \\
\text { (visceral metastases and/or } \geq 4 \text { bone } \\
\text { lesions with } \geq 1 \text { beyond vertebral } \\
\text { bodies and pelvis)? }\end{array}$ & $\begin{array}{l}\text { Yes, in the majority of } \\
\text { patients }\end{array}$ & $96 \%$ & $\begin{array}{l}95 / 120 \\
(79.17 \%)\end{array}$ & $\begin{array}{l}104 / 117 \\
(88.89 \%)\end{array}$ \\
\hline $\begin{array}{l}\text { Do you recommend docetaxel in } \\
\text { addition to ADT in men with de } \\
\text { novo metastatic castration-naïve and } \\
\text { low-volume disease as per } \\
\text { CHAARTED (no visceral } \\
\text { metastases and < } 4 \text { bone lesions and } \\
\text { only confined to axial skeleton)? }\end{array}$ & $\begin{array}{l}\text { Yes, in a minority of } \\
\text { selected patients }\end{array}$ & $65 \%$ & $\begin{array}{l}54 / 120 \\
(45.00 \%)\end{array}$ & $67 / 117(57.26 \%)$ \\
\hline $\begin{array}{l}\text { Do you recommend docetaxel in } \\
\text { addition to ADT in with metastatic } \\
\text { castration-naïve disease relapsing } \\
\text { after prior treatment for localized } \\
\text { prostate cancer and with high } \\
\text { volume disease as per CHAARTED } \\
\text { (visceral metastases and/or } \geq 4 \text { bone } \\
\text { lesions with } \geq 1 \text { beyond vertebral } \\
\text { bodies and pelvis)? }\end{array}$ & $\begin{array}{l}\text { Yes, in the majority of } \\
\text { patients }\end{array}$ & $74 \%$ & $\begin{array}{l}82 / 120 \\
(68.33 \%)\end{array}$ & $84 / 117(71.79 \%)$ \\
\hline $\begin{array}{l}\text { Do you recommend docetaxel in } \\
\text { addition to ADT in with metastatic } \\
\text { castration-naïve disease relapsing } \\
\text { after prior treatment for localized } \\
\text { prostate cancer with low volume } \\
\text { bone metastases as per } \\
\text { CHAARTED criteria (no visceral } \\
\text { metastases and < } 4 \text { bone lesions)? }\end{array}$ & $\begin{array}{l}\text { Yes, in a minority of } \\
\text { selected patients }\end{array}$ & $54 \%$ & $\begin{array}{l}47 / 120 \\
(39.17 \%)\end{array}$ & $63 / 117(53.85 \%)$ \\
\hline
\end{tabular}




\begin{tabular}{|c|c|c|c|c|}
\hline Question & Answer $^{\mathrm{a}}$ & Panelists $^{\mathrm{b}}$ & Pre-conference & Post-conference \\
\hline $\begin{array}{l}\text { If you use chemo-hormonal therapy } \\
\text { in men with metastatic castration- } \\
\text { naïve disease which chemotherapy } \\
\text { regimen do you recommend for the } \\
\text { majority of patients? }\end{array}$ & $\begin{array}{l}\text { 3-weekly regimen of } \\
\text { docetaxel with } \\
75 \mathrm{mg} / \mathrm{m}^{2}\end{array}$ & $96 \%$ & $\begin{array}{l}91 / 120 \\
(75.83 \%)\end{array}$ & $\begin{array}{l}102 / 117 \\
(87.18 \%)\end{array}$ \\
\hline $\begin{array}{l}\text { Do you recommend docetaxel in } \\
\text { addition to ADT in men with } \\
\text { castration-naïve (N1M0) prostate } \\
\text { cancer? }\end{array}$ & No & $71 \%$ & $\begin{array}{l}78 / 120 \\
(65.00 \%)\end{array}$ & $77 / 117(65.81 \%)$ \\
\hline $\begin{array}{l}\text { Do you recommend docetaxel in } \\
\text { addition to ADT in men with non- } \\
\text { metastatic castration-naïve (NOM0) } \\
\text { prostate cancer with biochemical } \\
\text { relapse? }\end{array}$ & No & $90 \%$ & $\begin{array}{l}103 / 120 \\
(85.83 \%)\end{array}$ & $\begin{array}{l}107 / 117 \\
(91.45 \%)\end{array}$ \\
\hline $\begin{array}{l}\text { What is your preferred first-line } \\
\text { mCRPC treatment option in the } \\
\text { majority of asymptomatic or } \\
\text { minimally symptomatic men who } \\
\text { did NOT receive docetaxel in the } \\
\text { castration-naïve setting? }\end{array}$ & $\begin{array}{l}\text { Abiraterone or } \\
\text { enzalutamide }\end{array}$ & $86 \%$ & $\begin{array}{l}98 / 120 \\
(81.67 \%)\end{array}$ & $\begin{array}{l}106 / 116 \\
(91.38 \%)\end{array}$ \\
\hline \multirow{2}{*}{$\begin{array}{l}\text { What is your preferred first-line } \\
\text { mCRPC treatment option in the } \\
\text { majority of symptomatic men who } \\
\text { did NOT receive docetaxel in the } \\
\text { castration-naïve setting? }\end{array}$} & $\begin{array}{l}\text { Abiraterone or } \\
\text { enzalutamide } \\
\text { (Panelists) }\end{array}$ & $52 \%$ & $\begin{array}{l}63 / 120 \\
(52.50 \%)\end{array}$ & $58 / 116(50.00 \%)$ \\
\hline & Docetaxel (Participants) & & & \\
\hline $\begin{array}{l}\text { What is your preferred first-line } \\
\text { mCRPC treatment option in the } \\
\text { majority of asymptomatic or } \\
\text { minimally symptomatic men who } \\
\text { did receive docetaxel in the } \\
\text { castration-naïve setting? }\end{array}$ & $\begin{array}{l}\text { Abiraterone or } \\
\text { enzalutamide }\end{array}$ & $90 \%$ & $\begin{array}{l}105 / 120 \\
(87.50 \%)\end{array}$ & $\begin{array}{l}110 / 116 \\
(94.83 \%)\end{array}$ \\
\hline $\begin{array}{l}\text { What is your preferred first-line } \\
\text { mCRPC treatment option in the } \\
\text { majority of symptomatic men who } \\
\text { did receive docetaxel in the } \\
\text { castration-naïve setting? }\end{array}$ & $\begin{array}{l}\text { Abiraterone or } \\
\text { enzalutamide }\end{array}$ & $73 \%$ & $\begin{array}{l}60 / 120 \\
(50.00 \%)\end{array}$ & $72 / 116(62.07 \%)$ \\
\hline $\begin{array}{l}\text { What is your preferred first-line } \\
\text { mCRPC treatment option in the } \\
\text { majority of asymptomatic or } \\
\text { minimally symptomatic men who } \\
\text { received chemo-hormonal therapy } \\
\text { and who progressed within } \leq 6 \\
\text { months of docetaxel in the } \\
\text { castration-naïve setting? }\end{array}$ & $\begin{array}{l}\text { Abiraterone or } \\
\text { enzalutamide }\end{array}$ & $77 \%$ & $\begin{array}{l}72 / 120 \\
(60.00 \%)\end{array}$ & $88 / 116(75.86 \%)$ \\
\hline
\end{tabular}




\begin{tabular}{|c|c|c|c|c|}
\hline Question & Answer $^{\mathrm{a}}$ & Panelists $^{b}$ & Pre-conference & Post-conference \\
\hline $\begin{array}{l}\text { What is your preferred first-line } \\
\text { mCRPC treatment option in the } \\
\text { majority of symptomatic men who } \\
\text { received chemo-hormonal therapy } \\
\text { and who progressed within } \leq 6 \\
\text { months of docetaxel in the } \\
\text { castration-naïve setting? }\end{array}$ & $\begin{array}{l}\text { Abiraterone or } \\
\text { enzalutamide } \\
\text { (Panelists) } \\
\text { Cabazitaxel } \\
\text { (Participants) }\end{array}$ & $57 \%$ & $\begin{array}{l}53 / 120 \\
(44.17 \%)\end{array}$ & $54 / 116(46.55 \%)$ \\
\hline $\begin{array}{l}\text { If you have to choose between } \\
\text { abiraterone and enzalutamide, what } \\
\text { is your preferred first-line choice for } \\
\text { men with mCRPC with no } \\
\text { contraindication to either drug? }\end{array}$ & $\begin{array}{l}\text { No preferred choice } \\
\text { (Panelists) } \\
\text { Abiraterone } \\
\text { (Participants) }\end{array}$ & $37 \%$ & $\begin{array}{l}39 / 120 \\
(32.50 \%)\end{array}$ & $41 / 116(35.34 \%)$ \\
\hline $\begin{array}{l}\text { When you use cabazitaxel for men } \\
\text { with mCRPC at any point in the } \\
\text { treatment sequence, which dose do } \\
\text { you recommend in the majority of } \\
\text { men? }\end{array}$ & $\begin{array}{l}\text { Cabazitaxel } 20 \mathrm{mg} / \mathrm{m}^{2} \text {, } \\
\text { with dose reductions in } \\
\text { subsequent cycles as } \\
\text { indicated }\end{array}$ & $59 \%$ & $\begin{array}{l}29 / 120 \\
(24.17 \%)\end{array}$ & $38 / 116(32.76 \%)$ \\
\hline $\begin{array}{l}\text { In men with mCRPC who are on } \\
\text { treatment with abiraterone or } \\
\text { enzalutamide for bone and soft } \\
\text { tissue metastases and who are } \\
\text { progressing only in the bone, do you } \\
\text { recommend the addition of radium- } \\
223 \text { ? }\end{array}$ & $\begin{array}{l}\text { Yes, in the majority of } \\
\text { patients (Panelists) } \\
\text { Yes, in the minority of } \\
\text { selected patients } \\
\text { (Participants) }\end{array}$ & $43 \%$ & $\begin{array}{l}45 / 120 \\
(37.50 \%)\end{array}$ & $51 / 116(43.97 \%)$ \\
\hline $\begin{array}{l}\text { In men with mCRPC who are on } \\
\text { treatment with radium- } 223 \text { and } \\
\text { progressing outside of the bone do } \\
\text { you recommend completing } \\
\text { treatment with radium- } 223 \text { plus } \\
\text { adding abiraterone or enzalutamide } \\
\text { (if they have not received either } \\
\text { drug before)? }\end{array}$ & $\begin{array}{l}\text { Yes, in the majority of } \\
\text { patients }\end{array}$ & $52 \%$ & $\begin{array}{l}40 / 120 \\
(33.33 \%)\end{array}$ & $49 / 116(42.24 \%)$ \\
\hline $\begin{array}{l}\text { What is your preferred second-line } \\
\text { mCRPC treatment option in the } \\
\text { majority of men with asymptomatic } \\
\text { mCRPC who had progressive } \\
\text { disease as best response to first-line } \\
\text { abiraterone or enzalutamide? }\end{array}$ & Taxane & $70 \%$ & $\begin{array}{l}72 / 120 \\
(60.00 \%)\end{array}$ & $82 / 116(70.69 \%)$ \\
\hline $\begin{array}{l}\text { What is your preferred second-line } \\
\text { mCRPC treatment option in the } \\
\text { majority of men with symptomatic } \\
\text { mCRPC who had progressive } \\
\text { disease as best response to first-line } \\
\text { abiraterone or enzalutamide? }\end{array}$ & Taxane & $96 \%$ & $\begin{array}{l}104 / 120 \\
(86.67 \%)\end{array}$ & $\begin{array}{l}102 / 116 \\
(87.93 \%)\end{array}$ \\
\hline
\end{tabular}




\begin{tabular}{|c|c|c|c|c|}
\hline Question & Answer $^{\mathrm{a}}$ & Panelists $^{b}$ & Pre-conference & Post-conference \\
\hline $\begin{array}{l}\text { What is your preferred second-line } \\
\text { mCRPC treatment option in the } \\
\text { majority of men with asymptomatic } \\
\text { mCRPC and acquired resistance } \\
\text { (initial response followed by } \\
\text { progression) after first-line } \\
\text { abiraterone or enzalutamide? }\end{array}$ & Taxane & $57 \%$ & $\begin{array}{l}71 / 120 \\
(59.17 \%)\end{array}$ & $81 / 116(69.83 \%)$ \\
\hline $\begin{array}{l}\text { What is your preferred second-line } \\
\text { mCRPC treatment option in the } \\
\text { majority of men with symptomatic } \\
\text { mCRPC and acquired resistance } \\
\text { (initial response followed by } \\
\text { progression) after use of first-line } \\
\text { abiraterone or enzalutamide? }\end{array}$ & Taxane & $90 \%$ & $\begin{array}{l}95 / 120 \\
(79.17 \%)\end{array}$ & $97 / 116(83.62 \%)$ \\
\hline $\begin{array}{l}\text { What is your preferred second-line } \\
\text { mCRPC treatment option in the } \\
\text { majority of asymptomatic/minimally } \\
\text { symptomatic men, progressing on or } \\
\text { after docetaxel for mCRPC (without } \\
\text { prior abiraterone or enzalutamide)? }\end{array}$ & $\begin{array}{l}\text { Abiraterone or } \\
\text { enzalutamide }\end{array}$ & $92 \%$ & $\begin{array}{l}103 / 120 \\
(85.83 \%)\end{array}$ & $\begin{array}{l}102 / 116 \\
(87.93 \%)\end{array}$ \\
\hline $\begin{array}{l}\text { What is your preferred second-line } \\
\text { mCRPC treatment option in the } \\
\text { majority of symptomatic men with } \\
\text { mCRPC, progressing on or after } \\
\text { docetaxel for mCRPC (without prior } \\
\text { abiraterone or enzalutamide)? }\end{array}$ & $\begin{array}{l}\text { Abiraterone or } \\
\text { enzalutamide }\end{array}$ & $76 \%$ & $\begin{array}{l}58 / 120 \\
(48.33 \%)\end{array}$ & $62 / 116(53.45 \%)$ \\
\hline $\begin{array}{l}\text { In men with mCRPC who have } \\
\text { exhausted approved treatments and } \\
\text { there is no clinical trial available, do } \\
\text { you recommend using carboplatin- } \\
\text { based chemotherapy? }\end{array}$ & $\begin{array}{l}\text { If DNA repair defect } \\
\text { present and/or } \\
\text { neuroendocrine } \\
\text { differentiation or } \\
\text { clinical evidence } \\
\text { suggestive of } \\
\text { neuroendocrine } \\
\text { differentiation }\end{array}$ & $47 \%$ & $\begin{array}{l}33 / 120 \\
(27.50 \%)\end{array}$ & $49 / 116(42.24 \%)$ \\
\hline $\begin{array}{l}\text { Which osteoclast-targeted therapy } \\
\text { do you recommend for men with } \\
\text { mCRPC and bone metastases for } \\
\text { SRE/SSE prevention? }\end{array}$ & Denosumab & $54 \%$ & $\begin{array}{l}54 / 120 \\
(45.00 \%)\end{array}$ & $57 / 116(49.14 \%)$ \\
\hline $\begin{array}{l}\text { When you use osteoclast-targeted } \\
\text { therapy (zoledronic acid or } \\
\text { denosumab) in men with mCRPC } \\
\text { and bone metastases, what treatment } \\
\text { duration do you recommend? }\end{array}$ & Approximately 2 years & $68 \%$ & $\begin{array}{l}64 / 120 \\
(53.33 \%)\end{array}$ & $87 / 116(75.00 \%)$ \\
\hline
\end{tabular}




\begin{tabular}{|c|c|c|c|c|}
\hline Question & Answer $^{\mathrm{a}}$ & Panelists $^{b}$ & Pre-conference & Post-conference \\
\hline $\begin{array}{l}\text { What monitoring by imaging do you } \\
\text { recommend for the majority of men } \\
\text { with metastatic castration- } \\
\text { sensitive/naïve prostate cancer? }\end{array}$ & $\begin{array}{l}\text { Baseline imaging and } \\
\text { follow-up imaging at } \\
\text { PSA nadir/completion } \\
\text { of } 6 \text { cycles of docetaxel } \\
\text { as part of chemo- } \\
\text { hormonal therapy and } \\
\text { again at progression } \\
\text { (confirmed PSA rise } \\
\text { and/or clinical } \\
\text { progression) }\end{array}$ & $51 \%$ & $\begin{array}{l}52 / 118 \\
(44.07 \%)\end{array}$ & $56 / 116(48.28 \%)$ \\
\hline $\begin{array}{l}\text { What kind of imaging do you } \\
\text { recommend for the majority of men } \\
\text { with metastatic castration-naïve } \\
\text { prostate cancer? }\end{array}$ & $\begin{array}{l}\mathrm{CT} \text { and bone } \\
\text { scintigraphy }\end{array}$ & $73 \%$ & $\begin{array}{l}97 / 118 \\
(82.20 \%)\end{array}$ & $84 / 116(72.41 \%)$ \\
\hline $\begin{array}{l}\text { What monitoring by imaging do you } \\
\text { recommend for the majority of men } \\
\text { on first-line mCRPC therapy? }\end{array}$ & $\begin{array}{l}\text { Baseline imaging and } \\
\text { regular monitoring by } \\
\text { imaging every } 3-6 \\
\text { months }\end{array}$ & $54 \%$ & $\begin{array}{l}45 / 118 \\
(38.14 \%)\end{array}$ & $51 / 116(43.97 \%)$ \\
\hline $\begin{array}{l}\text { What kind of imaging do you } \\
\text { recommend for the majority of men } \\
\text { with mCRPC on first-line therapy? }\end{array}$ & $\begin{array}{l}\mathrm{CT} \text { and bone } \\
\text { scintigraphy }\end{array}$ & $74 \%$ & $\begin{array}{l}94 / 118 \\
(79.66 \%)\end{array}$ & $82 / 116(70.69 \%)$ \\
\hline $\begin{array}{l}\text { Do you recommend genetic } \\
\text { counseling and testing for men with } \\
\text { newly diagnosed metastatic (M1) } \\
\text { prostate cancer? }\end{array}$ & $\begin{array}{l}\text { Yes, in a minority of } \\
\text { selected patients }\end{array}$ & $62 \%$ & $\begin{array}{l}58 / 118 \\
(49.15 \%)\end{array}$ & $76 / 116(65.52 \%)$ \\
\hline \multirow{2}{*}{$\begin{array}{l}\text { What imaging test is most suitable } \\
\text { to "exclude" distant metastases in } \\
\text { high-risk and locally-advanced } \\
\text { prostate cancer? }\end{array}$} & $\begin{array}{l}\text { CT and bone } \\
\text { scintigraphy (Panelists) }\end{array}$ & $41 \%$ & $\begin{array}{l}69 / 118 \\
(58.47 \%)\end{array}$ & $84 / 116(72.41 \%)$ \\
\hline & $\begin{array}{l}\text { PET/CT (PSMA, } \\
\text { choline, or fluciclovine) } \\
\text { (Participants) }\end{array}$ & & & \\
\hline $\begin{array}{l}\text { Would you add adjuvant RT in } \\
\text { high-risk localized PC patients with } \\
\text { seminal vesicle involvement alone? }\end{array}$ & $\begin{array}{l}\text { Yes, in the majority of } \\
\text { patients }\end{array}$ & $38 \%$ & $\begin{array}{l}36 / 117 \\
(30.77 \%)\end{array}$ & $43 / 116(37.07 \%)$ \\
\hline $\begin{array}{l}\text { Would you add adjuvant RT in } \\
\text { high-risk localized PC patients with } \\
\text { positive surgical margins alone? }\end{array}$ & $\begin{array}{l}\text { Yes, in the majority of } \\
\text { patients }\end{array}$ & $48 \%$ & $\begin{array}{l}54 / 117 \\
(46.15 \%)\end{array}$ & $47 / 116(40.52 \%)$ \\
\hline $\begin{array}{l}\text { Would you add adjuvant RT in } \\
\text { high-risk localized PC patients with } \\
\text { Gleason } 8-10 \text { or Gleason Grade } \\
\text { Group } 4 \text { or } 5 ?\end{array}$ & No & $55 \%$ & $\begin{array}{l}39 / 117 \\
(33.33 \%)\end{array}$ & $45 / 116(38.79 \%)$ \\
\hline $\begin{array}{l}\text { If you recommend adding ADT to } \\
\text { adjuvant radiation therapy what type } \\
\text { of ADT do you recommend in the } \\
\text { majority of men? }\end{array}$ & $\begin{array}{l}\text { LHRH } \\
\text { agonist/antagonist }\end{array}$ & $61 \%$ & $\begin{array}{l}80 / 117 \\
(68.38 \%)\end{array}$ & $82 / 116(70.69 \%)$ \\
\hline
\end{tabular}




\begin{tabular}{|c|c|c|c|c|}
\hline Question & Answer $^{\mathrm{a}}$ & Panelists $^{b}$ & Pre-conference & Post-conference \\
\hline $\begin{array}{l}\text { Do you recommend adjuvant } \\
\text { radiation therapy in men with pN1 } \\
\text { disease (adequate sampling) and no } \\
\text { local adverse factors (no pT3b, no } \\
\text { R1) and undetectable postoperative } \\
\text { PSA and who have recovered } \\
\text { urinary continence? }\end{array}$ & No & $43 \%$ & $\begin{array}{l}44 / 117 \\
(37.61 \%)\end{array}$ & $33 / 116(28.45 \%)$ \\
\hline $\begin{array}{l}\text { At what confirmed PSA level do } \\
\text { you recommend starting salvage } \\
\text { radiation therapy in the majority of } \\
\text { men with isolated rising PSA alone } \\
\text { after prostatectomy? }\end{array}$ & $0.2 \mathrm{ng} / \mathrm{mL}$ & $44 \%$ & $\begin{array}{l}61 / 117 \\
(52.14 \%)\end{array}$ & $82 / 116(70.69 \%)$ \\
\hline $\begin{array}{l}\text { Do you recommend adding ADT in } \\
\text { combination with salvage radiation } \\
\text { therapy? }\end{array}$ & $\begin{array}{l}\text { Yes, in the majority of } \\
\text { patients }\end{array}$ & $61 \%$ & $\begin{array}{l}34 / 117 \\
(29.06 \%)\end{array}$ & $57 / 116(49.14 \%)$ \\
\hline $\begin{array}{l}\text { In men with non-metastatic disease } \\
\text { and confirmed rising PSA (post- } \\
\text { local therapy }+/- \text { salvage local RT), } \\
\text { do you recommend starting ADT? }\end{array}$ & $\begin{array}{l}\text { In a minority of } \\
\text { selected patients e.g. } \\
\text { PSA } \geq 4 \mathrm{ng} / \mathrm{ml} \text { and rising } \\
\text { with doubling time less } \\
\text { than } 6 \text { months OR PSA } \\
\geq 20 \mathrm{ng} / \mathrm{ml} \\
\text { (STAMPEDE } \\
\text { inclusion criteria) }\end{array}$ & $65 \%$ & $\begin{array}{l}74 / 117 \\
(63.25 \%)\end{array}$ & $83 / 116(71.55 \%)$ \\
\hline $\begin{array}{l}\text { A clinically meaningful definition of } \\
\text { oligometastatic prostate cancer that } \\
\text { influences treatment decision (local } \\
\text { treatment of all lesions +/- systemic } \\
\text { therapy) includes: }\end{array}$ & $\begin{array}{l}\text { Only patients with a } \\
\text { limited number of bone } \\
\text { and/or lymph nodes } \\
\text { metastases that can be } \\
\text { treated with local } \\
\text { therapy }\end{array}$ & $61 \%$ & $\begin{array}{l}74 / 115 \\
(64.35 \%)\end{array}$ & $83 / 113(73.45 \%)$ \\
\hline $\begin{array}{l}\text { What is your cut-off for the number } \\
\text { of metastases to consider a patient } \\
\text { as oligometastatic? }\end{array}$ & $\leq 3$ metastases & $66 \%$ & $\begin{array}{l}56 / 115 \\
(48.70 \%)\end{array}$ & $80 / 113(70.80 \%)$ \\
\hline $\begin{array}{l}\text { In men with potentially de novo } \\
\text { oligometastatic disease what } \\
\text { imaging do you recommend to } \\
\text { confirm this diagnosis (apart from } \\
\text { local staging)? }\end{array}$ & $\begin{array}{l}\text { PET-CT (PSMA, } \\
\text { choline, or fluciclovine) }\end{array}$ & $34 \%$ & $\begin{array}{l}62 / 115 \\
(53.91 \%)\end{array}$ & $49 / 113(43.36 \%)$ \\
\hline $\begin{array}{l}\text { Which treatment do you recommend } \\
\text { in men with newly-diagnosed } \\
\text { oligometastatic prostate cancer with } \\
\text { an untreated primary? }\end{array}$ & $\begin{array}{l}\text { Local treatment } \\
(\text { surgery or RT })+\text { ADT } \\
24-36 \mathrm{~m}+/- \text { docetaxel }\end{array}$ & $31 \%$ & $\begin{array}{l}38 / 115 \\
(33.04 \%)\end{array}$ & $38 / 113(33.63 \%)$ \\
\hline $\begin{array}{l}\text { If you recommend radical local } \\
\text { treatment plus ADT in men with } \\
\text { newly diagnosed oligometastatic } \\
\text { prostate cancer and an untreated } \\
\text { primary do you recommend adding } \\
\text { docetaxel? }\end{array}$ & $\begin{array}{l}\text { Yes, in a minority of } \\
\text { selected patients } \\
\text { (Panelists) } \\
\text { No (Participants) }\end{array}$ & $39 \%$ & $\begin{array}{l}45 / 115 \\
(39.13 \%)\end{array}$ & $40 / 113(35.40 \%)$ \\
\hline
\end{tabular}




\begin{tabular}{|c|c|c|c|c|}
\hline Question & Answer $^{\mathrm{a}}$ & Panelists $^{b}$ & Pre-conference & Post-conference \\
\hline $\begin{array}{l}\text { In men with newly-diagnosed } \\
\text { oligometastatic prostate cancer and } \\
\text { an untreated primary what do you } \\
\text { recommend for treatment of the } \\
\text { primary? }\end{array}$ & Radiation therapy & $45 \%$ & $\begin{array}{l}41 / 115 \\
(35.65 \%)\end{array}$ & $49 / 113(43.36 \%)$ \\
\hline $\begin{array}{l}\text { What do you advise patients about } \\
\text { the relationship between ADT and } \\
\text { risk of bone loss and/or fractures? }\end{array}$ & $\begin{array}{l}\text { There is strong } \\
\text { evidence that ADT } \\
\text { increases risk of bone } \\
\text { loss and/or fractures }\end{array}$ & $87 \%$ & $\begin{array}{l}66 / 115 \\
(57.39 \%)\end{array}$ & $75 / 113(66.37 \%)$ \\
\hline $\begin{array}{l}\text { Do you recommend a baseline } \\
\text { measurement of vitamin } D \text { in men } \\
\text { with prostate cancer starting on } \\
\text { ADT? }\end{array}$ & $\begin{array}{l}\text { Yes, in the majority of } \\
\text { patients (Panelists) } \\
\text { No (Participants) }\end{array}$ & $43 \%$ & $\begin{array}{l}54 / 115 \\
(46.96 \%)\end{array}$ & $46 / 113(40.71 \%)$ \\
\hline $\begin{array}{l}\text { Do you recommend routine } \\
\text { supplementation of calcium and } \\
\text { vitamin D in the majority of men } \\
\text { with prostate cancer starting on } \\
\text { ADT? }\end{array}$ & Yes both & $73 \%$ & $\begin{array}{l}72 / 115 \\
(62.61 \%)\end{array}$ & $81 / 113(71.68 \%)$ \\
\hline $\begin{array}{l}\text { Do you recommend a baseline } \\
\text { measurement of bone mineral } \\
\text { density in men with prostate cancer } \\
\text { starting on ADT? }\end{array}$ & $\begin{array}{l}\text { Yes, in the majority of } \\
\text { patients (Panelists) } \\
\text { No (Participants) }\end{array}$ & $62 \%$ & $\begin{array}{l}55 / 115 \\
(47.83 \%)\end{array}$ & $43 / 113(38.05 \%)$ \\
\hline $\begin{array}{l}\text { Do you recommend drug therapy to } \\
\text { prevent bone loss and/or fractures } \\
\text { with denosumab or a } \\
\text { bisphosphonate for osteoporosis } \\
\text { prophylaxis in men with prostate } \\
\text { cancer starting on ADT? }\end{array}$ & $\begin{array}{l}\text { Only in patients with } \\
\text { documented osteopenia } \\
\text { or osteoporosis }\end{array}$ & $70 \%$ & $\begin{array}{l}49 / 115 \\
(42.61 \%)\end{array}$ & $67 / 113(59.29 \%)$ \\
\hline $\begin{array}{l}\text { Do you recommend regular physical } \\
\text { exercise in men with prostate cancer } \\
\text { starting on ADT? }\end{array}$ & $\begin{array}{l}\text { Yes, in the majority of } \\
\text { patients }\end{array}$ & $98 \%$ & $\begin{array}{l}105 / 115 \\
(91.30 \%)\end{array}$ & $\begin{array}{l}108 / 113 \\
(95.58 \%)\end{array}$ \\
\hline $\begin{array}{l}\text { Do you recommend to routinely } \\
\text { involve a multidisciplinary team for } \\
\text { prevention or management of ADT- } \\
\text { related adverse effects? }\end{array}$ & $\begin{array}{l}\text { Yes, in the majority of } \\
\text { patients (Panelists) } \\
\text { Yes, in a minority of } \\
\text { selected patients } \\
\text { (Participants) }\end{array}$ & $42 \%$ & $\begin{array}{l}29 / 115 \\
(25.22 \%)\end{array}$ & $51 / 113(45.13 \%)$ \\
\hline $\begin{array}{l}\text { Do you recommend a health status } \\
\text { assessment in men with advanced } \\
\text { prostate cancer } \geq 70 \text { years before } \\
\text { treatment decision? }\end{array}$ & $\begin{array}{l}\text { Yes, in a minority of } \\
\text { selected patients } \\
\text { (Panelists) } \\
\text { Yes, in the majority of } \\
\text { patients (Participants) }\end{array}$ & $42 \%$ & $\begin{array}{l}46 / 115 \\
(40.00 \%)\end{array}$ & $48 / 113(42.48 \%)$ \\
\hline $\begin{array}{l}\text { If you recommend a health status } \\
\text { assessment in men with advanced } \\
\text { prostate cancer } \geq 70 \text { years which one } \\
\text { do you recommend? }\end{array}$ & $\begin{array}{l}\text { Screening by G8 only } \\
\text { (followed by further } \\
\text { assessment if score } \\
\leq 14 \text { ) (Panelists) } \\
\text { Comprehensive } \\
\text { Geriatric Assessment } \\
\text { (Participants) }\end{array}$ & $30 \%$ & $\begin{array}{l}23 / 115 \\
(20.00 \%)\end{array}$ & $24 / 113(21.24 \%)$ \\
\hline
\end{tabular}




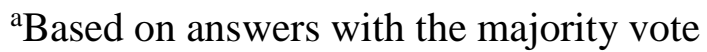

${ }^{\mathrm{b}}$ Based on APCCC 2017 [1]

${ }^{\mathrm{c}}$ Based on CHAARTED trial (Sweeney CJ, Chen YH, Carducci M, et al. Chemohormonal therapy in metastatic hormone-sensitive prostate cancer. N Engl J Med. 2015;373:737-746) ${ }^{\mathrm{d}}$ Based on STAMPEDE trial (James ND, Sydes MR, Clarke NW, et al. Addition of docetaxel, zoledronic acid, or both to first-line long-term hormone therapy in prostate cancer (STAMPEDE): survival results from an adaptive, multiarm, multistage, platform randomised controlled trial. Lancet. 2016;387:1163-1177)

ADT, androgen deprivation therapy; LHRH, luteinizing hormone-releasing hormone; AR, androgen receptor; mCRPC, metastatic castrate-resistant prostate cancer; SRE, skeletal-related events; SSE, symptomatic skeletal events; PSA, prostate-specific antigen; CT, computed tomography; PET-CT, positron emission tomography-computed tomography; PSMA, prostatespecific membrane antigen; RT, radiation therapy; PC, prostate cancer 


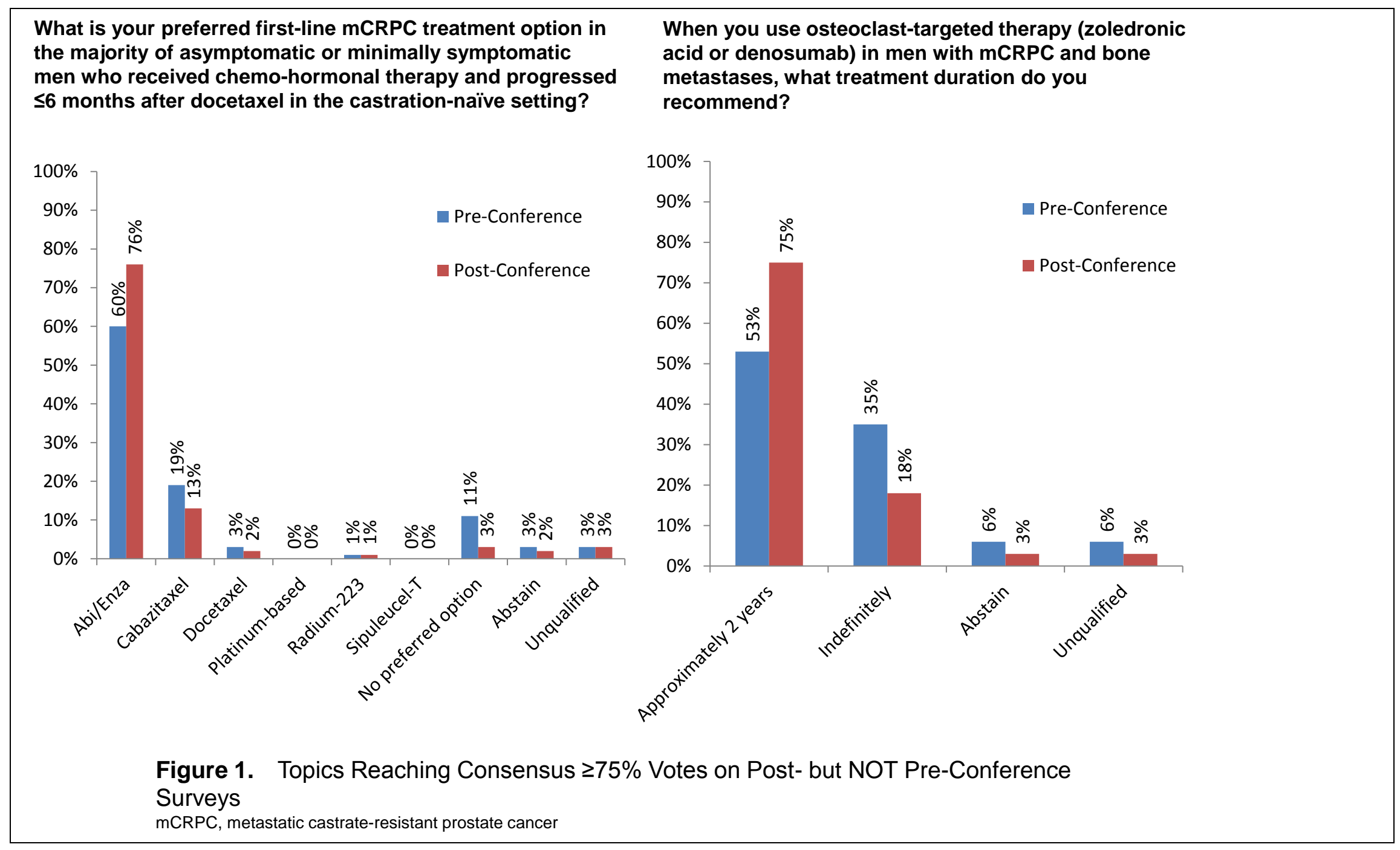




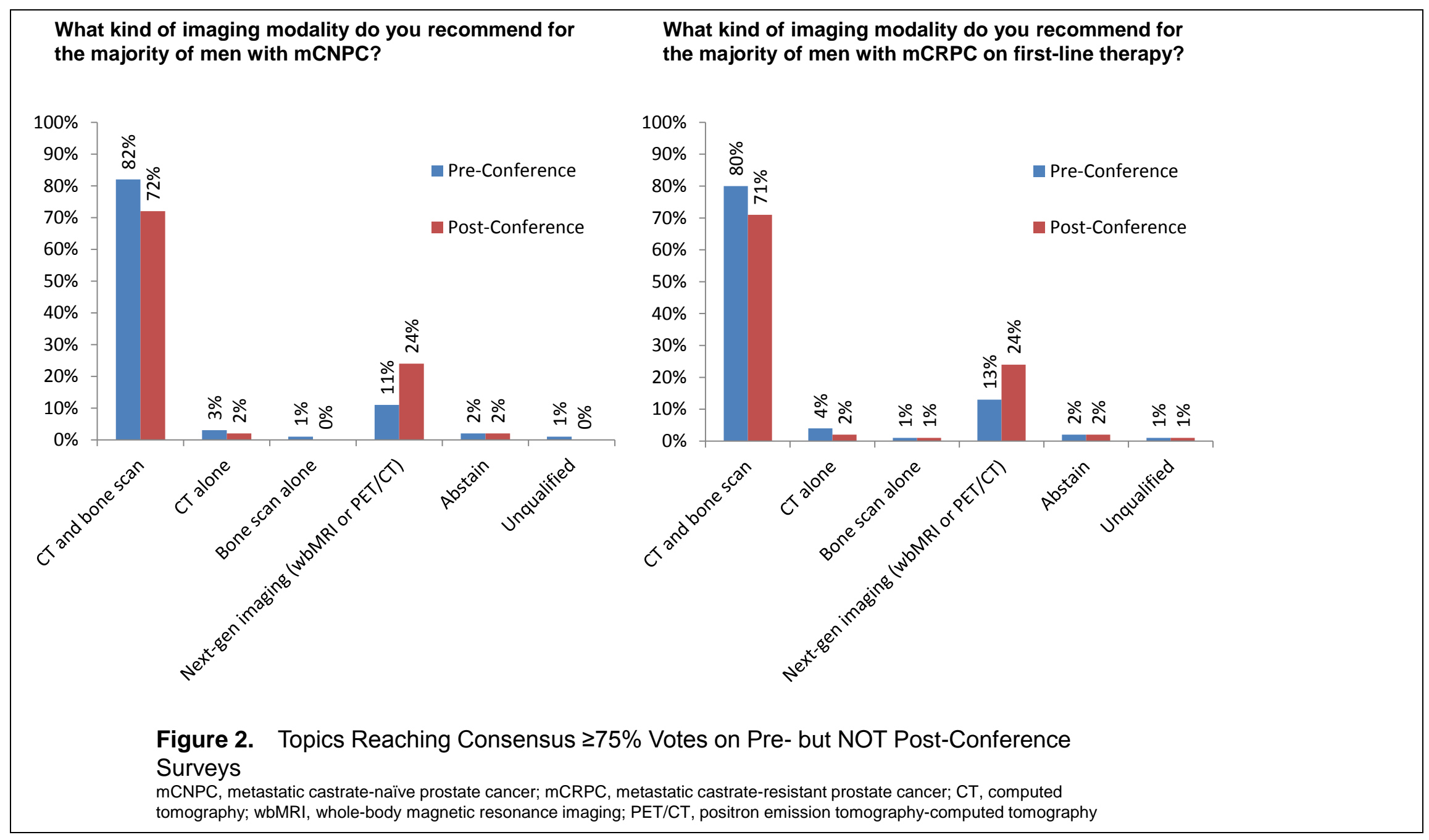

